UDK 630*1:502.175+630*4(497.11)"2018"

Original scientific paper

\title{
E FOREST VITALITY (ICP LEVEL I SAMPLE PLOTS) WITH A SPECIAL EMPHASIS ON BIOTIC AGENTS IN THE REPUBLIC OF SERBIA IN 2018
}

\author{
Renata GAGIĆ-SERDAR ${ }^{l}$, Tomislav STEFANOVIĆ ${ }^{1}$, Ilija ĐORĐEVIĆ ${ }^{l}$, \\ Goran ČE $\check{S} L J A R^{l}$, Miroslava MARKOVIĆ
}

\begin{abstract}
Dieback or degradation of forests is manifested as impaired tree vitality and it is the result of adverse effects of a set of abiotic and biotic factors on trees as living organisms and complex natural processes within forest biocoenoses. The agents classified into one of these two groups can act simultaneously or successively. The group whose share presents a great risk to the health of forests includes destructive insects or pathogenic fungi. Some insects occur together with fungi and their occurrence brings about a chain reaction that leads to a disease of the most common species on Level 1 sample plots - beech. Identification of the processes ongoing in forest ecosystems requires detailed research into environmental factors that lead to the occurrence of harmful insects. They often include changes in the climate. The next steps are to assess the condition of crown which is affected by this state, to determine the species of these organisms and their biology in general and to recognize other important agents that must be kept under control all with the aim of getting a deeper insight into all aspects of their effects on the health state of forest communities. One way to get a better insight into the state of forests and determine necessary improvement measures is to monitor the health state of forests. ICP Forests monitors the effects of harmful anthropogenic (mainly air pollution) and biotic factors on the state and development of forest ecosystems in Europe. Under the coordination of NFC National Focal Center of Serbia for monitoring at the Institute of Forestry in Belgrade, the forest monitoring system has been integrated into the state forestry environment with a number of institutions and their associates taking part in the programme.
\end{abstract}

Key words: forests, impacts, monitoring, pollution, crown condition

\footnotetext{
${ }^{1}$ Institute of forestry, Knaza Višeslava 3, 11000 Belgrade

Author of correspondence: Renata Gagić-Serdar Institute of forestry, Knaza Višeslava 3, 11000 Belgrade

e-mail:katas96@hotmail.com; serdarrenata79@gmail.com
} 


\title{
ВИТАЛНОСТ ШУМА (БИТ НИВО І ) РЕПУБЛИКЕ СРБИЈЕ СА ОСВРТОМ НА БИОТИЧКЕ АГЕНСЕ У 2018. ГОДИНИ
}

\author{
Рената ГАГИћ-СЕРДАР, Томислав СТЕФАНОВИЋ, Илија ЂОРЂЕВИЋ, \\ Горан ЧЕШљАР, Мирослава МАРКОВИЋ
}

\begin{abstract}
Апстракт: Сушење или пропадање шума огледа се кроз нарушену виталност стабала и последица је неповољног деловања комплекса фактора абиотичког и биотичког порекла на дрвеће као живе организме и сложене природне процесе унутар шумских биоценоза. Агенси сврстани у једну од ове две групе могу да делују истовремено или да се сукцесивно сменују. Група чије учешће спада међу оне високог рузика по здравствено стање шума јесу штетни инсекти или патогене гљиве. Неки се инсекти јављају заједно са гљивама и појава су уланчаног деловања које проузрокује честу болест букве, најбројније врсте на БИТ НИВО-а 1. Утврђивање процеса у иумским екосистемима захтева детаљна истраживања еколошких фактора који доводе до појаве итетних инсеката за које су понекад довољне и промена климе, затим одређивање стања крошњи које подлегну њиховом утииају, врстама ових организама и у целости юиховој биологији као важним агенсима који се морају држати под контролом не би ли се потпуно имао увид у све аспекте деловања истих на шумске заједнице. Увид у стање шума ради доношења закључака о потребним мерама унапређења, могуће је установити кроз праћ ење кондиционог стања шума. Предмет рада ICР-а за шуме су праћење антропогеног (превасходно ваздушно загађење) и биотичких штетних фактора на стање и развој шумских екосистема Европе. Под коориднацијом Управе за шуме и НФЦ- националног фокал иентра Републике Србије за праћење стања шума у Институту за иумарство у Београду, систем праћења стања иума интегрисан је у државно шумарско окружење, тако да у програму учествује неколико институиија са својим сарадницима.
\end{abstract}

Кључне речи: шума, утицаји, мониторинг, загађење, стање круна

\section{INTRODUCTION}

CLRTAP $^{1}$ program was established 25 years ago with the aim of reducing air pollution in Europe. Data are collected on over 6000 sample plots in more than 40 countries and used for the purposes of Level I crown condition monitoring. The assessment of crown condition through discolourisation, defoliation, and determination of damage to trees caused by diseases and pests on SPs in 2018 makes a significant contribution to the final conclusions on adverse effects of a complex of abiotic and biotic factors in Serbia, the region and throughout the whole of Europe. These indicators were assessed and the damage was recorded by types on all sample plots in Serbia. This paper is based on data from field reports or forms filled in the field by researchers of the Institute of Forestry. The basic data are supplemented by notes made on the description of vegetation and the agents of diseases and plant pests on the trees sampled on the plots. The National Focal Center at the Institute of Forestry in the Republic of Serbia has been participating

${ }^{1}$ CLRTAP Convention on Long-Range Transboundary Air Pollution 
in the international program of ICP Forests with a tendency to expand the work and harmonize it with other working approaches to monitoring of forests and forest ecosystems.

Difficulties in the interpretation of results, as well as their occasional variations emphasize the importance of continuous monitoring of defoliation, as well as additional assessments of various environmental data that can contribute to better understanding of the cause-effect relationships that bring about the so-called 'damage' to sample trees. The next step in assessing the condition of sample trees (dieback and chlorosis) is the integral monitoring of the system by determining changes in healthy functioning and phenology, which are caused by factors that can be discovered by additional research. First of all, we should mention a large number of species of forest insects, as well as those species that occur in conjunction with phytopathogens as chain agents of more complex phenomena such as beech disease as the most common species of sample trees on Level I sample plots.

Continuous Level I monitoring of forest condition in accordance with the ICP Manual (2010) and the ICP programme has been implemented on reconstructed sample plots - experimental fields since 2002. The coordination and management of the activities on the ICP Forests programme have been entrusted to the Institute of Forestry (the National Focal Center of the Republic of Serbia for monitoring the condition of forests) by the Ministry of Agriculture, Forestry and Water Management of the Republic of Serbia - Forest Directorate. Since 2002, our country has been actively participating in this programme and reporting to the Forest Directorate every year. The Level I monitoring of forest condition is primarily related to the observation and assessment of defoliation and discolouration of tree crowns on certain sample plots, the results of which are published and delivered to the scientific and professional environment.

\section{RESEARCH AREA, METHOD AND CRITERIA}

Forest condition monitoring is one of the largest forest bio-monitoring systems that is implemented in order to detect changes in forests using key ecological parameters. On the basis of the obtained data, it is possible to determine spatial and temporal trends in the state of forests, i.e., tree species and their crown condition by region. A wider context can include the correlation of the crown condition data with the data obtained from corresponding sample plots as well as external data on natural and human stress factors, which all provide some indications of the interrelations between the forest vitality and stress factors.

In the period from 2002 to 2018 , a total of 130 sample plots arranged in 16 $\mathrm{x} 16 \mathrm{~km}$ and $4 \mathrm{x} 4 \mathrm{~km}$ grids have been established in the territory of the Republic of Serbia. (Nevenić et al., 2006). In 2018, the condition of forest species was assessed on all 130 sample plots in Serbia.

Institute of Forestry teams conducted field visits of sample plots in the area of forest estates in the presence of experts, forest inspectors, forest engineers and technicians responsible for the particular sample plot localities or areas. 
Visual monitoring, conducted according to the ICP Forests Manual, was carried out on the sample plots in the territory of the Republic of Serbia. It included crown condition assessment and determination of damage caused by diseases and pests. According to ICP Forests Manual, crown condition assessments are mandatory on all plots once a year, soil condition assessments every ten years as well as the assessment of the nutritional condition of forest trees - foliar analysis.

A sample plot is determined by its coordinates and its center is marked with a metal rod of a vivid colour. Trees are systematically sampled for the purpose of crown condition assessment. As they are selected in 4-point clusters, it makes a total of 24 trees. In the direction of the 4 cardinal points at a distance of $25 \mathrm{~m}$ from the center, six closest trees are selected for the purpose of crown condition monitoring. Tree samples include all tree species with a minimum height of $60 \mathrm{~cm}$. The crown canopy classes after $\mathrm{Kraft}^{1}$ (dominant, co-dominant, subdominant, suppressed and dying), are used as a criterion for selecting trees, excluding trees with significant mechanical injury. The selected trees are permanently marked with numbers for the future continuous assessments. The trees which are removed due to management measures or for some other reasons are replaced with new ones. If a stand is clear-felled, the central point is kept until the establishment of a new stand.

Within the framework of national and transnational research (Level I), the crown condition is assessed by the classes of defoliation, discolouration and combined damage classes. Defoliation is assessed in 5\% intervals and it is classified into 5 groups of uneven range (Table 1).

Table 1. Classes of defoliation according to UN/ECE ${ }^{2}$ and $E U^{3}$ classification

\begin{tabular}{|c|c|c|}
\hline Classes of defoliation - dieback & Degree of defoliation & Leaf loss (\%) \\
\hline 0 & No & $0-10$ \\
\hline 1 & Slight & $10-25$ \\
\hline 2 & Moderate & $25-60$ \\
\hline 3 & Severe & $60-100$ \\
\hline 4 & Dead & 100 \\
\hline
\end{tabular}

Since 2018, the research has been improved in practice by introducing purposeful forms used in the monitoring of damage and its agents on sample plots. The forms are processed using a code system that gives a deeper insight into the state of each of the trees in terms of the pests or diseases that affect this tree. Abiotic factors are also included because, although they are primary agents, they give rise to secondary damage agents and make it easier for insects and fungi to infest once healthy trees. These are the reasons we have been sampling and monitoring trees all these years trying to put all pieces together and get the whole picture.

\footnotetext{
${ }^{1}$ The modified concept of the crown canopy classification, the traditional measurement of variables used in forestry, first applied by Kraft, in Germany, in the nineteenth century, (1884)

${ }^{2}$ United Nations Economic Commission for Europe

${ }^{3}$ European Union
} 


\section{RESULTS ON THE HEALTH CONDITION OF TREES ON LEVEL I SAMPLE PLOTS IN 2018}

Health condition, effects of damaging agents - Apart from the results of the tree crown condition assessments, damaging agents, i.e., a great number of disease-causing organisms and pests, (Nevenić et al., 2006) were determined in the forest ecosystems of the established sample plots. Pathogenic epixylic fungi and harmful insects are the accompanying organisms of some natural ecosystems. To minimize their destructive activity, forest management includes tending measures whose aim is to reduce their populations to an acceptable measure, i.e., abundance that will not cause evident damage (Mihajlović, 2008). However, the pollution that occurs in the conditions of climate change makes the agents of diseases and pests change their usual rhythms and bionomy. Some parasites disappear, while others become more active under these altered, new conditions.

The damage to trees was recorded according to the agent and the species of trees where they were detected. The most common agents were harmful insects and fungi, as dominant biotic factors, and human activity (in cutting, felling and hauling, which increases the risk for the damaged trees to be penetrated and infested by diseases and pests in previously healthy trees).

Table 2. The damage on the sample plots presented by agents in $2018(\%)$

\begin{tabular}{|c|r|r|r|r|r|r|r|c|}
\hline Species & Insects & Fungi & $\begin{array}{c}\text { Abiotic } \\
\text { agents }\end{array}$ & Human & Fire & $\begin{array}{c}\text { Local } \\
\text { pollution }\end{array}$ & $\begin{array}{c}\text { Other } \\
\text { damage }\end{array}$ & $\begin{array}{c}\text { Total } \\
\text { damage }\end{array}$ \\
\hline All species & 9,4 & 9,1 & 2,8 & 0,9 & 0,4 & 0 & 6,5 & 29,1 \\
\hline Broadleaves & 10,7 & 10,1 & 3 & 1 & 0,5 & 0 & 6,3 & 31,6 \\
\hline Conifers & 0,3 & 1,7 & 1,1 & 0,3 & 0 & 0 & 8,4 & 11,8 \\
\hline Beech & 9,4 & 13,4 & 5,4 & 2,3 & 0,6 & 0 & 7,1 & 38,2 \\
\hline Sessile oak & 17,7 & 5,1 & 1,5 & 0,5 & 0 & 0 & 10,1 & 34,9 \\
\hline Turkey oak & 9,9 & 7,7 & 4,4 & 0 & 0,4 & 0 & 6,3 & 28,7 \\
\hline Fir & 0 & 0 & 3 & 0 & 0 & 0 & 21,2 & 24,2 \\
\hline $\begin{array}{c}\text { Norway } \\
\text { spruce }\end{array}$ & 0 & 0 & 1,4 & 0 & 0 & 0 & 9,7 & 11,1 \\
\hline $\begin{array}{c}\text { Austrian } \\
\text { pine }\end{array}$ & 0 & 9 & 0 & 0 & 0 & 0 & 0 & 9 \\
\hline
\end{tabular}

\section{DISCUSSION}

The most common species of coniferous forests are Austrian pine, Scots pine, Norway spruce and fir. After the recognition of the above-mentioned forest areas and the identification of the agents of defoliation and discolourisation caused by diseases and pests, the damage can be best described by listing the names and percentages of the most frequent ones (Nevenić et al., 2012). The health status of coniferous forests in 2018 was generally better compared to broadleaved forests. 
Of all conifers, Austrian pine had the smallest share of damage (Table 2). Several types of pathogens and a slightly smaller number of epixylic fungi were registered.

A dangerous pathogen - Micopshaerella pini Rost.in Munc (1957) occurred in 2018, but only on the previous-year needles of Austrian pine, and on a small scale. In the butt-end, several disease-causing fungi were found, the most common of which was Fomitopsis pinicola (Swartz: Fr.) Karst (1871), (Figure 1). Almost $10 \%$ of Austrian pine trees had symptoms of attacks of the aforementioned pathogens and wood-decaying fungi.

The needles of Scots pine were affected by M. pini, Lophodermium pinastri (Schard.:Fr.)Chev(1826) and Lophodermium seditiosum Minter, Staley \& Millar (1978) - on a small scale. Stems and branches also registered F. pinicola and Trichaptum sp. The needles of Scots pine also registered the damage typical of the attack of Diprion pini L. insect. Several physiologically-weakened trees had visible tunnels of Buprestidae (SP 45). Globally, the health status of Scots pine trees was better this year. However, a lot of trees were severely damaged during felling and hauling and the inflicted damage is a threat in the coming period as it makes trees susceptible to the attack of a number of harmful insects and diseases.

In the stands of Norway spruce, the needles were affected by a dangerous pathogen, Lophodermium piceae, but on a small scale. It should be noted that Chermes species also occurred on individual trees. Of the significant wooddecaying fungi, a very dangerous root-decaying fungus Heterobasidion parviporum Niemelä \& Korhonen 1998 was registered, but only on individual trees (Nevenić et al., 2014). The most common pests in Norway spruce forests were the bark beetles - primarily Ips typographus L., (Figure 2), which were found in the locations with dying, hollowed Norway spruce trees (the area of NP Kopaonik, SP in the areas of certain protection regimes).

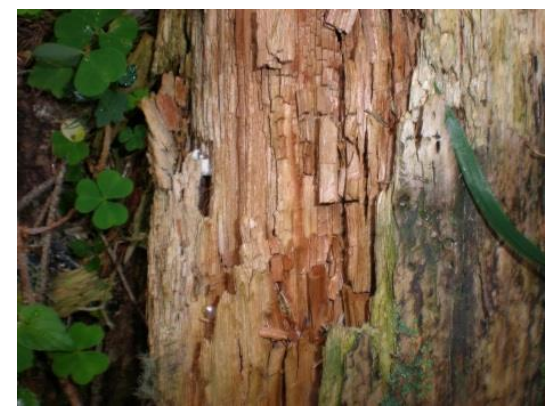

Figure 1. SP 65, brown cubic rot in the butt end of a pine tree (Orig.)

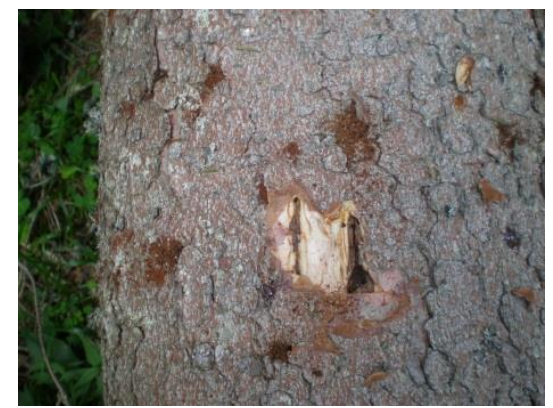

Figure 2. SP 419, exit holes of bark beetles Ips typographus (|Orig.)

The most frequent fungi occurring on the fir sample plots were Cytospora friesii Sacc. (1884) and Lirula nervisequa (DC.ex Fr.) Darker (1967) but only on a small scale. The presence of a number of 'witches` brooms`caused by the parasitic fungus Mellampsorella caryophyllacearum, Schrot (1864) was registered on three sample plots - SP 401, 402, 418. Of the epixylic fungi that destroy the wood mass, a small-scale presence of Armillariella ostoyae (Romang Hering. 1973) was registered. The symptoms of plant diseases and wood destruction caused by the above-mentioned agents were clearly visible in $9.1 \%$ of the observed trees. A 
significant resin bleeding was observed in several fir trees. It can be due to numerous factors, but the final result is the death of trees in a period of two to three years.

The most common broadleaved tree species on sample plots are oaks sessile oak, Turkey oak and Hungarian oak, and include stands of different ages. Young privately-owned sessile oak coppice forests (Quercus petraea L.) are of poor health condition (SP 78), while the sessile oak forests in the territory of 'Djerdap' National Park have a satisfactory health state due to the proper implementation of the protection regime and tending measures, (SP 33).

On the leaves of mature trees and young crop, several types of pathogenic fungi were registered, the most common of which were powdery mildews Microsphaera alphitoides Griffon \& Maubl (1910), (Fig. 3) and Mycosphaerella maculiformis (Pers. J. Schrot. 1894) that cause leaf blight. The most common insects causing damage to oak leaves were defoliators (Geometridae) and leaf rollers (Tortricidae. Cynipidae, especially the species Neuroterus quercus baccarum L., were found on Turkey oak trees, on a significant scale (SP 36, 38, 39). The most common causes of damage to oak leaves (on almost all Level I sample plots with oak trees) were miners, with Tischeria and Stigmella being the most common genera on all oaks (Figures 4 and 5). The individual presence of the nests of oak processionary - Thaumetopoea processionea L. was also recorded.

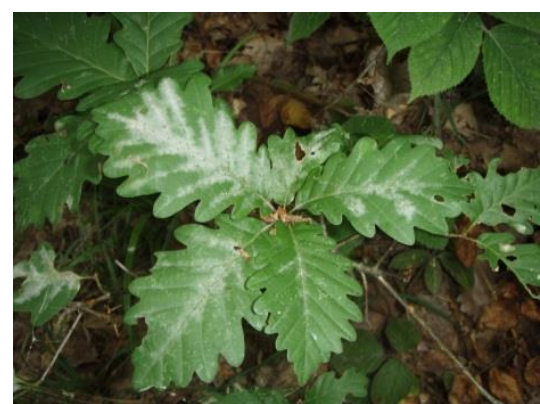

Figure 3. SP 21 Microsphaera alphitoides on young oak trees (Orig.)

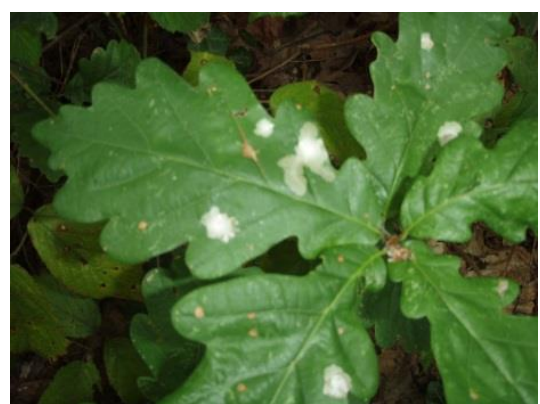

Figure 4. SP 19 Miners - Ticheria ekebladella on young oak trees (Orig.)

Several wood-decaying fungi were registered on the branches of Turkey oak trees, but they are represented on a small scale and thus have no significance.

There were several types of damage on the trunks of oak trees, some of which were very important and dangerous. Bacterial tumorous forms that occur on trunks can reach large proportions, but this time they occurred only individually and in untended stands. Oak trees had conks of the wood-decaying fungus Armillaria Hartig (1873) on the butt-ends and Fomes fomentarius L. ex. Fr. Kickx (1867) on the trunks, as well as the brown central rot which occurred mainly on damaged trees. On sample plots 48 and 60 , a very dangerous epixylic fungus Laetiporus sulphureus (Bull.ex Fr.Murr (1920), which has the characteristics of both parasites and saprophytes, started its growth on healthy standing trees and continued on felled trees leading to the complete decomposition of wood mass. 
Dieback of sessile oak trees was also present. It was caused by the action of a number of detrimental factors, dating from previous years and getting worse every year.

Other biotic agents of damage included parasitic flowering plants - white mistletoe (Viscum album L.) and yellow mistletoe (Loranthus europaeus Jacq.) on individual branches of oak trees. They caused physiological weakening of trees and made them prone to the attack of dangerous wood destructors and pests.

The forest litter of the sample plots contains fungi that are characteristic of the observed types of forests (Zúbrik et al., 2008), some of which cause rotting in the butt-ends - such as Armillaria sp. and Hypoxylon deustum Hoffm.Grev. (1828). The damage caused by fungi occurred in almost $30 \%$ of trees.

Abiotic factors included frost shake on the bark of Hungarian oak trees, which were present on a small scale, while the damage to the leaves was very pronounced. Mechanical damage to oak trees was registered in more than $25 \%$ of the studied trees and they were caused by human factor, i.e. during tree felling and hauling. These injuries pose a potential danger and make trees prone to many harmful insects, disease-causing fungi, as well as wood-destroying organisms (Vajda, 1974).

Besides oaks, a large number of sample plots include beech forests (Fagus moessaca L). Despite its good technical characteristics, beech wood is known to be quite susceptible to the attacks of numerous parasitic and saprophytic organisms. Their action makes physiologically weakened and diseased trees an easy target for various primary and secondary harmful insect species, which in the end results in the death of both individual trees and groups of trees (Tabaković -Tošić, Marković, 2004).

Insect damage was registered on beech leaves. It was done mainly by miners Orchestes fagi L. and Lithocolletis faginella (Zeller, 1864). Gall makers occurred very often, the most common of which were Hartigiola anullipes (Hartig, 1939) and Mycioola fagi (Hartig, 1939).

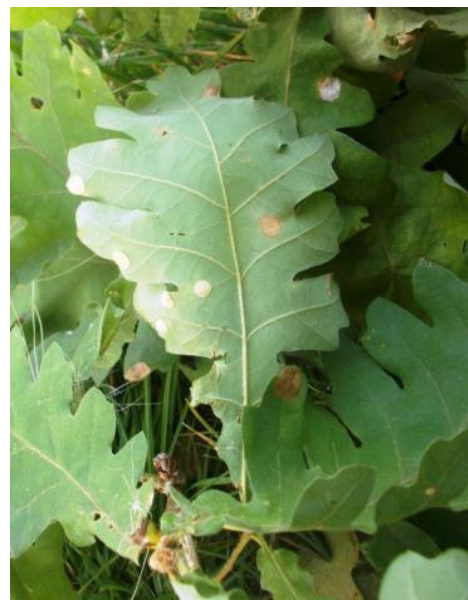

Figure 5. SP 49 damage by miners on Turkey oak (Orig.)

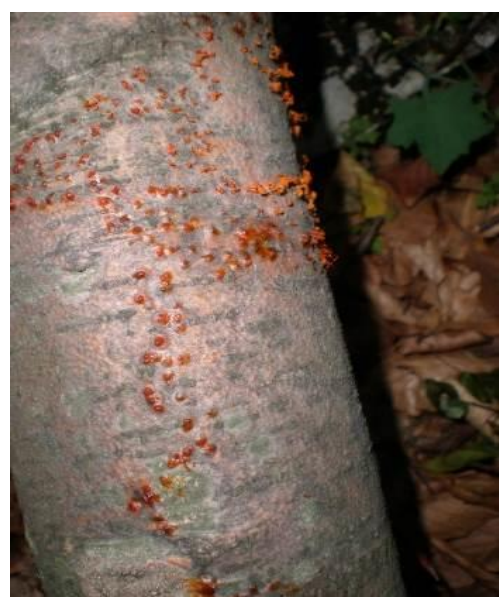

Figure 6. $S P 58$ Nectria sp. on the felled beech log (Orig.) 
The symptoms of fungus attacks on trunks were present in $13.4 \%$ of beech trees. Diatrype disciformis (Hoffm.) Fr. and cankers were registered on the bark. There were several species of wood-decaying fungi on the butt-end of the stem but on a small scale.

Regarding mechanical factors that caused damage to mature beech trees in 2014, it should be noted that it can be mostly attributed to ice-breaks (SP 413). It is important to note the occurrence of ice-breaks because they initiate a chain action that starts with the destruction of an entire stand due to the canopy opening and bark burn that subsequently arise a whole chain of biotic agents that lead to the complete devastation of beech forests (Češljar et al., 2013).

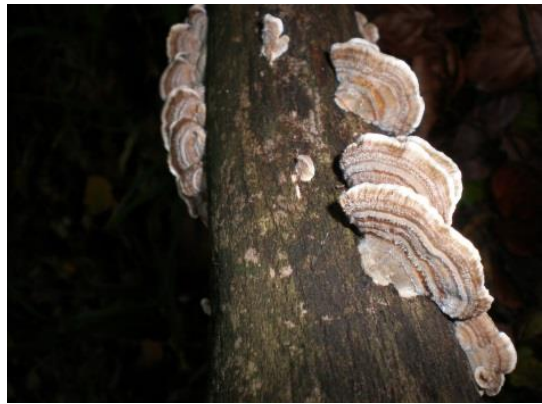

Figure 7. SP 51 Trametes versicolor on the felled beech logs (Orig.)

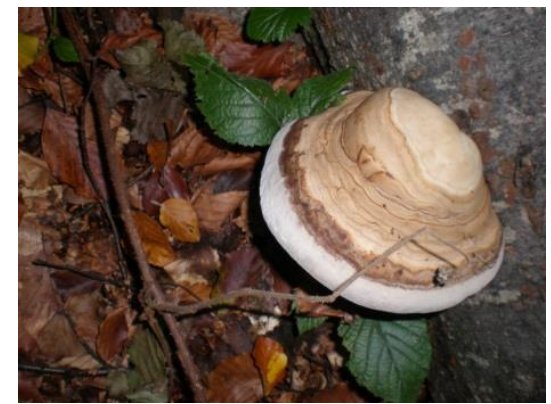

Figure 8. SP 61 Fomes fomentarius on the felled beech logs (Orig.)

The presence of Diatrype stigma (Hoffm.) Fr. was registered on the branches and a large number of conks of $F$. fomentarius (Fig. 8) on the felled logs. Nectria coccinea was also abundant and together with Cryptococcus fagisuga, Lindinger, 1936, caused the so-called 'beech bark disease', which is a common occurrence on beech SPs, especially in the ones with an open canopy.

Figure 6 shows the fruiting bodies of Nectria cinnabarina (Tode) Fr., (1849). There are a lot of decayed trees attacked by the wood-decaying fungus Trametes versicolor L.ex.Fr.Pilat (1936), (Figure 7). Generally, beech is the most common species in our country and it is of good health condition. However, these agents of damage have endangered it in certain localities and made it prone to further spread of dangerous diseases and pests (Marković et al., 2014). Therefore, there is a pressing need for frequent monitoring of the state and proper implementation of forestry measures in order to minimize damage (Marković et al., 2014).

\section{CONCLUSIONS}

The aim of the crown condition assessment (discolourisation, defoliation and damage) was not only to determine the current cause-effect relationships. The data collected over a long time period and their correlation with stand characteristics will give us a deeper insight into the causes of forest dying and determine its future trends. 
Defoliation had similar trends in broadleaves and conifers in 2018, but it was more frequent than discolourisation for both groups of trees. Therefore discolourisation is no longer as a significant parameter as it used to be. The types of damage were also determined and registered. Because of the attack of a large number of the above-mentioned diseases and pests and the greater presence of mechanical injuries, the broadleaves had more pronounced discolourisation, which is why they are briefly presented as more frequent. Harmful agents, numerous agents of diseases, and pests were registered on the trees sampled for monitoring on sample plots.

The vitality of forests depends on environmental conditions and a great number of biotic and abiotic factors, such as climatic characteristics, atmospheric deposition, harmful insects, pathogenic organisms, wood mass destroyers, forest fires, direct atmospheric impacts, game, rodents, (Nevenić et al., 2008). Nevertheless, biotic agents are the most important factor threatening the trees sampled and monitored for more than a decade and a half in continuity. Therefore, further analysis can provide different trends of their direct effects and degrees of their effects. International program for further and more detailed monitoring of the forest condition in the Republic of Serbia (ICP Forests), which is carried out on Level I sample plots, will enable us to determine the vitality of forests both at the local and at the regional level.

Acknowledgments: This paper is a result of a research carried within the Project "Development of technological methods in forestry in order to attain optimal forest cover" (TR 31070, Led by Ljubinko Rakonjac, financed by the Ministry of education, science and technological development of the Republic of Serbia and Project "Monitoring and assessment of air pollution and it's effects on forest ecosystems in Serbia - Forest condition monitoring", financed by the ministry of agriculture and environment protection of the Republic of Serbia - Forest Directorate).

\section{REFERENCES}

Vajda, Z. (1974): Forest Protection Science, University book, Zagreb, Školska knjiga

Češljar G., Nevenić, R., Bilibajkić S., Stefanović T., Renata Gagić-Serdar R., Đorđević I., Poduška Z., (2013): Viability Of Trees On Level I Sample Plots In The Republic Of Serbia In 2013, SUSTAINABLE FORESTRY Collection 67-68, Institute Of Forestry, Belgrade, pp. $69-78$

Mihajlović, Lj. (2008): Forest Entomology, University book, Belgrade, Faculty of Forestry

Marković M, Rajković S, Nevenić, R. (2014): The Most Frequent Agents Of Damage Of Trees On The Sample Plots In Serbia: SUSTAINABLE FORESTRY Collection Of Papers 69-70, Institute Of Forestry, Belgrade, pp. 85-94

Nevenić et al., (2006): Monitoring of the state of forests in the Republic of Serbia. Annual report for 2006. National Focal Center of Serbia (NFC) ICP Forests - LEVEL 1. Institute of Forestry. Belgrade, Serbia, p.102.

Nevenić et al., (2008): Monitoring of the state of forests in the Republic of Serbia according to the ICP Forest Programme (International Cooperative Programme for 
Monitoring the State of the Forests of Europe) and the CLTRAP Convention (Convention on Transboundary Air Pollution Transmission). Annual report for 2008. National Focal Center of Serbia (NFC). ICP Forests - Level I. Institute of Forestry. Belgrade Serbia. p. 15.

Nevenić, R., Tabaković-Tošić M., Rajković S., Rakonjac Lj., Miletić Z., Marković M., Bilibajkić S., Stefanović T., Stajić S., Čokeša V., Radulović Z., Poduška Z., Gagić-Serdar R., Đorđević I., Češljar G., (2012): Assessment and monitoring of the effects of air pollution on forest ecosystems in Serbia. Level I and Level II. ISSN 1425/8576

Nevenić R., Tabaković-Tošić M., Rajković S., Rakonjac Lj., Miletić Z., Marković M., Bilibajkić S., Stefanović T., Stajić S., Čokeša V., Radulović Z., Poduška Z., Gagić-Serdar R., Đorđević I., Česljar G., (2014): Assessment and monitoring of the effects of air pollution on forest ecosystems in the Republic of Serbia. Level I and Level II. (Chapters 4, $5,6,7,9,10,13,16)$ ISBN 987-86-80439-35-8

Tabaković Tošić, M. and Marković, M., (2004): Effects of phytophagous insects on the health condition of beech forests of Eastern Serbia. Proceedings, Collection 50-51. Institute of Forestry, Belgrade, p.56.

Zúbrik, M., Kunca, A., Novotný, J. (2008): Hmyz Huby, Atlas poškodeni lesných drevin, Institutum Forestale Zvolen

*****(2010): Manual on methods and criteria for harmonized sampling, assessment, monitoring and analysis of the effects of air pollution on forests, United Nations Economic Commission For Europe Convention On Long-Range Transboundary Air Pollution,. Institute for World Forestry. Programme Coordinating Centre of ICP Forests.

\title{
FOREST VITALITY (ICP LEVEL I SAMPLE PLOTS) WITH A SPECIAL EMPHASIS ON BIOTIC AGENTS IN THE REPUBLIC OF SERBIA IN 2018
}

\author{
Renata GAGIĆ-SERDAR, Tomislav STEFANOVIĆ, Ilija ĐORĐEVIĆ, \\ Goran ČE $\check{L} L A R$, Miroslava MARKOVIĆ
}

\section{Summary}

National Focal Center at the Institute of Forestry in the Republic of Serbia has been continuously participating in an international program of ICP Forests since 2003 with a tendency to expand the work and harmonize it with other working approaches to monitoring of forests and forest ecosystems. The assessment of crown condition through defoliation and tree damage caused by diseases and pests performed on ICP Sample Plots in 2018 make a significant contribution to reaching the final conclusions on declining forest vitality. It is a result of adverse effects of a complex of abiotic and biotic factors on trees as living organisms and complex natural processes within the forest biocoenoses. The impact of pollutants and climate change factors on the vitality of forests is an evident phenomenon in Serbia, the region and throughout the whole of Europe. These topics are arising great interest and they are yet to be the focus of research both in our country and in the world. 


\title{
ВИТАЛНОСТ ШУМА (БИТ НИВО І ) РЕПУБЛИКЕ СРБИЈЕ СА ОСВРТОМ НА БИОТИЧКЕ АГЕНСЕ У 2018. ГОДИНИ
}

\author{
Рената ГАГИЋ-СЕРДАР, Томислав СТЕФАНОВИЋ, Илија ЂОРЋЕВИЋ, \\ Горан ЧЕШљАР, Мирослава МАРКОВИТ
}

\section{Резиме}

Национални фокал центар у Институту за шумарство, за праћење стања шума Републике Србије од 2003. године у континуитету учествује у међународном програму ICP за шуме са тенденцијом даљег усавршавања рада и усклађивања са другим приступима рада на праћењу стања шума и шумских екосистема. Процена стања круна, кроз дефолијацију, и установљавање оштећења на дрвећу од болести и штеточина, на БИТ у 2018. години, допринос је извођењу коначних закључака о нарушеној виталності шума. Она се јавља као последица неповољног деловања комплекса фактора абиотичког и биотичког порекла на дрвеће као живе организме и сложене природне процесе унутар шумских биоценоза. Утицај загађивача и измена фактора климе на виталност шума евидентан као појава, у Србији, региону и читавој Европи. Истраживања ове тематике веома су актулна и тек ће бити предмет рада, код нас и у свету. 